Omni-Akuatika, 13 (1): 60-65, 2017
ISSN: 1858-3873 print / 2476-9347 online
Research Article

\title{
Chronosequence Effect of Post Tin Mining Ponds to Metals Residu and Microecosystem Change
}

\author{
Andri Kurniawan ${ }^{1)}$ \\ ${ }^{1)}$ Department of Aquaculture, Bangka Belitung University, Indonesia \\ Jl. Balunijuk, Merawang, Bangka Belitung Archipelago Province 33172, Indonesia \\ ${ }^{*}$ Corresponding author: andri_pangkal@yahoo.co.id \\ Received 20 February 2017; Accepted 30 March 2017; Available online 31 May 2017
}

\begin{abstract}
The ecological change that caused by tin mining activity was among the most important sorts of problem in the environment, including heavy metals contamination and change of microecosystem. This article aims to identify speciation of metals and heavy metals in post tin mining aquatic ecosystem, particularly, disused tin mining ponds in West Bangka, Indonesia in a chronosequence effect study. Speciation of metals and heavy metals were detected by X-Ray Fluorescence. X-Ray Fluorescence analysis showed that heavy metals in post tin mining ponds like $\mathrm{Fe}, \mathrm{Sn}$, and $\mathrm{Cu}$ and also some metals like $\mathrm{Mg}, \mathrm{Si}, \mathrm{Al}, \mathrm{S}$, and $\mathrm{P}$ were detected with a different numbers. There was a speciation of heavy metals and metals in post tin mining ponds with chronosequence effect. It can become an important and basic study about potential bioremediator in the research locations. Further, researches about microecosystem change and interaction of microorganisms and heavy metals there can become information to design an ecological management tool to manage this ecosystem so it can be used for primay or secondary activity.
\end{abstract}

Keywords: chronosequence effect, metals residu, microecosystem, post tin mining ponds, $x$-ray fluorescence

\section{Introduction}

Tin mining activity had contributed to ecological problems such as threat to natural reserves due to landscape changes, damage to natural drainage, pollution, heavy metals contamination and destruction of natural habitats (Ashraf et al., 2010; Ashraf et al., 2012a; Daniel et al., 2014). Heavy metals contamination in the environment have created a very difficult situation for a healthy life (Verma et al., 2011) because of its persistence, biomagnifications, and accumulation in the environment and along to in food chain (Rajendran et al., 2003) by agricultural products (Jaiswal, 2011) or animal (Lone et al., 2008) and then cause a serious threat to human health (Rai, 2008).

Some researches have done to detect heavy metals in tin mining activity, such as in Bangka of Indonesia (Henny, 2011; Rosidah and Henny, 2012), in Malaysia (Ashraf et al., 2012a), and in Nigeria (Daniel et al., 2014). However, a chronosequence effect of post tin mining ponds ecosystem to heavy metals, particularly, in West Bangka, Indonesia have not be done. While, an understanding of heavy metals dynamic in a chronosequence effect was crucial in order to predict ecosystem conditions and detect environment changes. Further, it becomes an important part to determine the next aquatic ecosystem management.

\section{Material and Method}

The study areas were located in West Bangka Regency, Bangka Belitung Archipelago Province of Indonesia. The considered study sites cover five ponds of post tin mining with differences of ponds' age and the mining activity that refers to once used or reused for tin mining activity in these areas. The study areas were encoded K.Ex I (2०06'21.1'S; $105^{\circ}$ 39'12.7"E);K.Ex II (2०06'20.7"S; 105 39'11.3"E); K.P (206 '45.7'S; $\left.105^{\circ} 39^{\prime} 17.7^{\prime \prime} \mathrm{E}\right)$; K.As I (2 ${ }^{\circ} 06^{\prime}$ 11.3"S; $\left.105^{\circ} 40^{\prime} 16.0^{\prime \prime} \mathrm{E}\right) ;$ and K.As II (206'12.5"S; $\left.105^{\circ} 40^{\prime} 15.6^{\prime \prime} \mathrm{E}\right)$.

The parameters of research include $\mathrm{pH}$ value, water temperature, total disolved solids (TDS), and heavy metals and metals contamintion. In methods, $\mathrm{pH}$ value was 
analyzed by $\mathrm{pH}$ meter, water temperature was analyzed by digital thermometer, TDS was analyzed by TDS meter, and metals or heavy metals were analyzed by X-Ray Fluorescence.

\section{Results and Discussion}

In this research, chronosequence effects to basic parameters analyzed such as $\mathrm{pH}$, TDS, and water temperature, and particularly, chronosequence effect to ecological characteristics and chronosequence effect to metals and heavy metals shown in Table $\mathbf{1}$ and Table 2.

Tin mining activity had generated ponds with degradated ecological composition and structure quality and also physical or biological characteristics, macro and micro ecosystems change (Vyas and Pancholi, 2009; Giri et al., 2014; Lad et al., 2015). The study about water quality and heavy metals in water of post mining area shows that there were variations in the environmnt (Ashraf et al., 2011). Each water body has patterns of physical and chemical characteristics which were determined largely by the climatic, geomorphological, and geochemical conditions prevailing in the drainage basin and the underlying aquifer (Ashraf et al., 2012b).

The $\mathrm{pH}$ value in the research locations showed that an acidic conditions. In K.Ex I and K.Ex II sites, $\mathrm{pH}$ value were very extreme acidic in 1,7-1,9. In K.P, K.As I, and K.As II sites show $\mathrm{pH}$ value were 2,2-4,7. Acidic waste waters from industrial and mining activities was known as acid mine drainage (AMD) waters that often highly acidic $(\mathrm{pH}<4)$ (Kolmert and Johnson, 2001) as a results of sulfide minerals oxidization (principally pyrite, $\mathrm{FeS}_{2}$ ) after the mine wastes were exposed to oxygen and water (Tan et al., 2007). The age and mining activity also contribute to change of $\mathrm{pH}$ value. The age of ecosystem has a correlation with ecological succession were followed nutrient cycling and physico-chemical characteristics (Moreno-de las Heras et al., 2008).

Table 1. Chronosequence effect to ecological characteristics

\begin{tabular}{|c|c|c|c|c|c|c|}
\hline $\begin{array}{l}\text { Location } \\
\text { Code }\end{array}$ & $\begin{array}{c}\text { Age } \\
\text { (year) }\end{array}$ & The mining activity & Depth & $\mathrm{pH}$ & TDS (ppm) & $\begin{array}{c}\text { Temperatur } \\
\left({ }^{\circ} \mathrm{C}\right)\end{array}$ \\
\hline K.Ex I & $>50$ & $\begin{array}{l}\text { Reused (more than once } \\
\text { until now) }\end{array}$ & $\begin{array}{l}<2 \mathrm{~m} \\
>2 \mathrm{~m}\end{array}$ & $\begin{array}{c}1,7 \\
1,8- \\
2,1\end{array}$ & $\begin{array}{l}944-972 \\
942-990\end{array}$ & $\begin{array}{l}29,1-29,7 \\
29,6-29,8\end{array}$ \\
\hline \multirow[t]{2}{*}{ K.Ex II } & $>50$ & $\begin{array}{l}\text { Reused (more than once } \\
\text { until now) }\end{array}$ & $<2 m$ & $\begin{array}{c}1,7- \\
1,9\end{array}$ & $968-979$ & $29,0-29,5$ \\
\hline & & & $>2 m$ & $\begin{array}{c}1,7- \\
1,8\end{array}$ & $969-1050$ & $28,3-28,6$ \\
\hline \multirow[t]{2}{*}{ K.P } & $>50$ & Once used & $<2 m$ & $\begin{array}{l}2,3- \\
2,6\end{array}$ & $430-447$ & $29,7-31,1$ \\
\hline & & & $>2 m$ & $\begin{array}{l}2,2- \\
2,4\end{array}$ & $411-437$ & $29,3-31,0$ \\
\hline \multirow[t]{2}{*}{ K.As I } & $>10$ & Once used & $<2 m$ & $\begin{array}{c}4,4- \\
4,6\end{array}$ & $0,14-0,19$ & $29,1-31,5$ \\
\hline & & & $>2 m$ & $\begin{array}{c}4,6- \\
4,7\end{array}$ & $0,14-0,17$ & $28,7-30,4$ \\
\hline \multirow[t]{2}{*}{ K.As II } & $>10$ & Once used & $<2 \mathrm{~m}$ & $\begin{array}{c}4,3- \\
4,4\end{array}$ & $0,11-0,18$ & $27,7-28,8$ \\
\hline & & & $>2 m$ & $\begin{array}{c}4,6- \\
4,7\end{array}$ & $0,15-0,16$ & $27,8-28,7$ \\
\hline
\end{tabular}

Table 2. Chronosequence effect to heavy metals and metals

\begin{tabular}{|c|c|c|c|c|c|c|c|c|}
\hline \multirow{2}{*}{$\begin{array}{c}\text { Location } \\
\text { Code }\end{array}$} & \multicolumn{8}{|c|}{ Heavy Metals / Metals (ppm) } \\
\hline & $\mathrm{Fe}$ & Sn & $\mathrm{Cu}$ & $\mathrm{Mg}$ & $\mathrm{Si}$ & $\mathrm{Al}$ & $\mathrm{S}$ & $P$ \\
\hline K.Ex I & $472-527$ & $\begin{array}{c}48,3- \\
50,0\end{array}$ & $\begin{array}{c}4,05- \\
4,26\end{array}$ & $\geq 51,1$ & $\begin{array}{c}12.900- \\
13.600\end{array}$ & $\begin{array}{c}8.320- \\
8.760\end{array}$ & $801-830$ & $\begin{array}{c}16,9- \\
21,2\end{array}$ \\
\hline K.Ex II & $\begin{array}{c}73,2- \\
76,4\end{array}$ & $\begin{array}{c}48,9- \\
50,0\end{array}$ & $\begin{array}{c}3,03- \\
3,42\end{array}$ & $712-794$ & $109-110$ & $237-279$ & $380-389$ & $4,81-6,4$ \\
\hline K.P & $\begin{array}{c}15,3- \\
16,1\end{array}$ & $\begin{array}{c}49,0- \\
50,7\end{array}$ & $\begin{array}{c}2,80- \\
4,29\end{array}$ & $794-829$ & $250-277$ & $251-294$ & $89,5-93,2$ & $\begin{array}{c}7,74- \\
7,84\end{array}$ \\
\hline K.As I & $196-204$ & $\begin{array}{c}47,6- \\
51,6\end{array}$ & $\begin{array}{c}4,95- \\
5,92\end{array}$ & $638-752$ & $2570-2870$ & $\begin{array}{c}2480- \\
2860\end{array}$ & $15,2-18,5$ & $\begin{array}{c}18,3- \\
18,8\end{array}$ \\
\hline K.As II & $\begin{array}{c}10,5- \\
18,6\end{array}$ & $\begin{array}{c}50,6- \\
50,8\end{array}$ & $\begin{array}{c}4,69- \\
7,45\end{array}$ & $839-907$ & $218-254$ & $335-394$ & $7,54-8,09$ & $\begin{array}{c}10,2- \\
10,5\end{array}$ \\
\hline
\end{tabular}


The chonosequence effects were taken also in metals and heavy metals speciation. In K.Ex I and K.Ex II sites have higher metals and heavy metals number than others sites. An acid water can dissolve and mobilize heavy metals (like $\mathrm{Pb}, \mathrm{Zn}, \mathrm{Cu}, \mathrm{Ni}, \mathrm{Cd}$ ), transport, and release them into the environment (Modoi et al., 2014). Further, the mobility of metals, in particular, heavy metals depend not only on $\mathrm{pH}$ value, but also on total concentration, their specific chemical form, their binding state, the metal properties, and the environmental factors and properties like organic matter content (Rodri'guez et al., 2009).

The change of ecosystem in post tin mining as well as in others mining ecosystem, certainly followed the changes of organisms and including microbial communities structure (Grant et al., 2007). Changes of microorganisms in abundance and their composition were investigated during succession (Urbanov'a et al., 2011) and mining significantly altered microorganism communities (Banning et al., 2011). In other study, microorganisms' activity can accelerate dissolution of minerals, particularly, pyrite and other sulfide minerals in derelict mine sites, including many that have been long-abandoned (Johnson and Hallberg, 2003). The acidhopile activity can used tailing of mining as nutition, carbon, and nitrogen source with mixotrophy as a chemoheterotroph and a photoautotroph (Hao et al., 2010) to generate a succession in disturbed ecosystem for a long process (Rowe et al., 2007; Fierer et al., 2010; Lo'pez-Lozano et al., 2013).

Interesting to discussed, the change of post tin mining waters ecological characteristics that impact to microorganisms diversity and structures like methane-oxidizing bacteria (MOB), ammonia-oxidizing bacteria (AOB) (Sow et al., 2014a; Sow et al., 2014b) and arsenic-resistant bacteria (ARB) (Jareonmit et al., 2010; Valverde et al., 2011) or otherwise the microorganisms activity had effects to ecological change including speciation of metals and heavy metals and also post tin mining waters ecosystem characteristics in the chronesequence. The change of ecosystem properties along chronosequence as a result of environemental evolution can drive microbial communities function and diversity (Banner et al., 2011) or their capability to survive in ecosystem age evolution (Chodak et al., 2009) in resistance (insensitivity to disturbance) and resilience (the rate of recovery after disturbance) (Shade et al., 2012) for carbon, nitrogen, sulfur cycling, and metals (Xie et al., 2011) can drive ecological change.
There was a significant correlations were found between the microorganism communities and also geochemical factors (Vishnivetskaya et al., 2011). Ecological factors, including heavy metal pollution had a significant impact on microbial communities structure and functional diversity (Liao and Xie, 2007), size and activity (Wang et al., 2007), and microbial communities composition and diversity change along chemical gradients (Bier et al., 2015). But also, microorganisms play a significant role in remediations of contaminated ecosystem (Akhtar et al., 2013; Iram and Abrar, 2015) have been used in environmental cleanups (Kumar et al., 2010; Nagashetti et al., 2013). The interactions of heavy metals and microorganisms in chronosequence effect of post mining, particularly, in post tin mining waters ecosystem needs to be undertaken for a justification so that it become a solution to accelerate the recovery of water sources for secondary activities and habitable for organisms.

\section{References}

Akhtar, S., Mahmood-ul-Hassan, M., Ahmad, R., Suthor, V.,Yasin, M. 2013. Metal tolerance potential of filamentous fungi isolated from soils irrigated with untreated municipal effluent. Soil Environ 32(1): 55-62.

Ashraf, MA., Maah, MJ., Yusoff, I. 2010. Study of water quality and heavy metals in soil $\&$ water of ex-mining area Bestari Jaya, Peninsular Malaysia. International Journal of Basic \& Applied Sciences IJBAS-IJENS 10(3): 7-12.

Ashraf, MA., Maah, MJ., Yusoff, I. 2011. Analysis of physio-chemical parameters and distribution of heavy metals in soil and water of ex-mining area of Bestari Jaya, Peninsular Mal aysia. Asian Journal of Chemistry 23(8): 3493-3499.

Ashraf, MA., Maah, MJ., Yusoff, I. 2012a. Speciation of heavy metals in the sediments of former tin mining catchment. Iranian Journal of Science and Technology 36(A2): 163-180.

Ashraf, MA., Maah, MJ., Yusoff, I. 2012b. Morphology, geology and water quality assessment of former tin mining catchment. The Scientific World Journal 2012: 1-15. DOI:10.1100/2012/369206.

Banning, NC., Gleeson, DB., Grigg, AH., Grant, CD., Andersen, GL., Brodie, EL., Murphy, DV. 2011. Soil microbial 
community successional patterns during forest ecosystem restoration. Applied and Environmental Microbiology 77(17): 6158-6164.

Bier RL., Voss, KA., Bernhardt, ES. 2015. Bacterial community responses to a gradient of alkaline mountaintop mine drainage in central appalachian streams. ISME Journal 9(6): 1378-1390.

Chodak, M., Pietrzykowski, M., Niklińska, M. 2009. Development of microbial properties in a chronosequence of sandy mine soils. Applied Soil Ecology 41(3): 259-268.

Daniel, VN., Chudusu, ES., Chup, JA., Pius, ND. 2014. Variations of heavy metals in agricultural soils irrigated with tin water in Heipang District of Barkin Ladi, Plateau State, Nigeria. International Journal of Science and Technology 3(5): 255-263.

Fierer, N., Nemergut, D., Knight, R., Craine, JM. 2010. Changes through time: integrating microorganisms into the study of succession. Research in Microbiology 161(8): 635-642.

Giri, K., Mishra, G., Pandey, S., Verma, PK., Kumar, R., Bisht, NS. 2014. Ecological degradation in northeastern coal fields: Margherita Assam. International Journal of Science, Environment and Technology 3(3): 881-884.

Grant, RJ., Muckian, LM., Clipson, NJ., Doyle, EM. 2007. Microbial community changes during the bioremediation of creosotecontaminated soil. Letters in Applied Microbiology 44(3): 293-300.

Hao, C., Wang, L., Gao, Y., Zhang, L., Dong, H. 2010. Microbial diversity in acid mine drainage of Xiang Mountain sulfide mine, Anhui Province, China. Extremophiles 14(5): 465-474.

Henny, C. 2011. Bioakumulasi beberapa logam pada ikan di kolong bekas tambang timah di Pulau Bangka. Limnotek 18(1): 83-95.

Iram, S., Abrar, S. 2015. Biosorption of copper and lead by heavy metal resistant fungal isolates. International Journal of Scientific and Research Publications 5(1): $1-5$.

Jaiswal, S. 2011. Role of Rhizobacteria in reduction of arsenic uptake by plants: a review. Journal of Bioremediation \& Biodegradation 2(4): 1-5.
Jareonmit, P., Sajjaphan, K., Sadowsky, MJ. 2010. Structure and diversity of arsenicresistant bacteria in an old tin mine area of Thailand. Journal of Microbiology and Biotechnology 20(1): 169-178.

Johnson, DB., Hallberg, KB. 2003. Mini-review: the microbiology of acidic mine waters. Reseach in Microbiology 154(7): 466473.

Kolmert, A., Johnson, DB. 2001. Remediation of acidic waste waters using immobilised, acidophilic sulfate-reducing bacteria. Chemical Technology and Biotechnology 76(8): 836-843.

Kumar, A., Bisht, BS., Joshi, VD. 2010. Biosorption of heavy metals by four acclimated microbial species, Bacillus spp., Pseudomonas spp., Staphylococcus spp. and Aspergillus niger. Journal of Biological and Environmental Sciences 4(12): 97-108.

Lad, RJ., Samant, JS. 2015. Impact of bauxite mining on soil: a case study of bauxite mines at Udgiri, Dist-Kolhapur, Maharashtra State, India. International Research Journal of Environment Sciences 4(2): 77-83.

Liao, M., Xie, XM. 2007. Effect of heavy metals on substrate utilization pattern, biomass, and activity of microbial communities in a reclaimed mining wasteland of red soil area. Ecotoxicology and Environmental Safety 66(2): 217-223.

Lo'pez-Lozano, NE., Heidelberg, KB., Nelson, WC., Garćla-Oliva, F., Eguiarte, LE., Souza, V. 2013. Microbial secondary succession in soil microcosms of a desert oasis in the cuatro cienegas basin, Mexico. PeerJ 1(e47): 1-22.

Lone, MI., He, ZL., Stoffella, PJ., Yang, X. 2008. Phytoremediation of heavy metal polluted soils and water: progresses and perspectives. Journal of Zhejiang University Science B 9(3): 210-220.

Modoi, O., Roba, C., Török, Z., Ozunu, A. 2014. Environmental risks due to heavy metal pollution of water resulted from mining wastes in Nw Romania. Environmental Engineering and Management Journal 13(9): 2325-2336.

Moreno-de las Heras, M., Nicolau, JM., Espigares, T. 2008. Vegetation succession in reclaimed coal-mining slopes in a mediterranean-dry 
environment. Ecological Engineering 34(2): 168-178.

Nagashetti, V., Mahadevaraju, GK., Muralidhar, TS., Javed, A., Trivedi, D., Bhusal, KP. 2013. Biosorption of heavy metals from soil by Pseudomonas aeruginosa. International Journal of Innovative Technology and Exploring Engineering 2 (6): 22-24.

Rai, PK. 2008. Heavy metal pollution in aquatic ecosystems and its phytoremediation using wetland plants: an ecosustainable approach. International Journal of Phytoremediation 10(2): 131-58.

Rajendran, P., Muthukrishnan, J., Gunasekaran, P. 2003. Microbes in heavy metal remediation. Indian Journal of Experimental Biology 41(9): 935-944.

Rodri'guez, L., Ruiz, E., Alonso-Azca'rate, J., Rinco'n, J. 2009. Heavy metal distribution and chemical speciation in tailings and soils around a $\mathrm{Pb}-\mathrm{Zn}$ mine in Spain. Journal of Environmental Management 90(2): 1106-1116.

Rosidah., Henny, C. 2012. Kajian logam Fe, Al, $\mathrm{Cu}$ dan $\mathrm{Zn}$ pada perairan kolong paska penambangan timah di Pulau Bangka. [Prosiding]. Seminar Nasional Limnologi VI Tahun 2012 [Indonesia].

Rowe, OF., Sanchez-Espana, J., Hallberg KB., Johnson, DB. 2007. Microbial communities and geochemical dynamics in an extremly acid, metal-rich stream at an abandoned sulfide mine (Huelva Spain) underpinned by two fuctional primary production systems. Environmental Microbiology 9(7): 17611771.

Shade, A., Peter, H., Allison, SD., Baho, DL., Berga, M., Bürgmann, H., Huber, DH., Langenheder, S., Lennon, JT., Martiny, JBH., Matulich, KL., Schmidt, TM., Handelsman, J. 2012. Fundamentals of microbial community resistance and resilience. Frontiers in Microbiology 3(417): 1-19.

Sow, SLS., Khoo, G., Chong, LK., Smith, TJ., Harrison, PL., Ong, HKA. 2014a. molecular diversity of the ammoniaoxidizing bacteria community in disused tin-mining ponds located within Kampar, Perak, Malaysia. World Journal of Microbiology and Biotechnology 30(2): 757-766.
Sow, SLS., Khoo G., Chong, LK., Smith, TJ., Harrison, PL., Ong, HKA. 2014b. Molecular diversity of the methanotrophic bacteria communities associated with disused tin-mining ponds in Kampar, Perak, Malaysia. World Journal of Microbiology and Biotechnology 30(10): 2645-2653.

Tan, G., Shu, W., Hallberg, KB., Li, F., Lan, C., Huang, L. 2007. Cultivation-dependent and cultivation-independent characterization of the microbial community in acid mine drainage associated with acidic $\mathrm{Pb} / \mathrm{Zn}$ mine tailings at Lechang, Guangdong, China. FEMS Microbiology Ecology 59(1): 118126.

Urbanov'a, M., Kopecky', J., Val'as`kov'a, V., S'agov'a-Marec'kov'a, M., Elhottov'a, D., Kyselkov'a, M., Moe"nne-Loccoz, Y., Baldrian, P. 2011. Development of bacterial community during spontaneous succession on spoil heaps after brown coal mining. FEMS Microbiology Ecology 78(1): 59-69.

Valverde, A., González-Tirante, M., MedinaSierra, M., Santa-Regina, I., GarcíaSánchez, A., Igual, JM. 2011. Diversity and community structure of culturable arsenic-resistant bacteria across a soil arsenic gradient at an abandoned Tungsten-tin mining area. Chemosphere 85(2011): 129-134.

Verma, DK., Gupta, AP. 2011. Removal of heavy metals from whole sphere by plants working as bioindicators - a review. Basic Research Journal of Pharmaceutical Science 1(1): 1-7.

Vishnivetskaya, AT., Mosher, JJ., Palumbo, AV., Yang, ZK., Podar, M., Brown, SD., Brooks, SC., Gu, B., Southworth, GR., Drake, MM., Brandt, CC., Elias, DA. 2011. Mercury and other heavy metals influence bacterial community structure in contaminated Tennessee streams. Applied and Environmental Microbiology 77(1): 302-311.

Vyas, A., Pancholi, A. 2009. Environmental degradation due to mining in South Rajasthan: a case study of Nimbahera, Chittorgarh (India). Journal of Environmental Research and Development 4(2): 405-412.

Wang, YP., Shi, JY., Wang, H., Lin, Q., Chen, XC., Chen, YX. 2007. The influence of soil heavy metals pollution on soil microbial biomass, enzyme activity, and 
community composition near a copper smelter. Ecotoxicology and Environmental Safety 67(1): 75-81.

Xie, J., He, Z., Liu, X., Liu, X., Nostrand, JDV., Deng, Y., Wu, L., Zhou, J., Qiu, G. 2011.
Geochip-based analysis of the functional gene diversity and metabolic potential of microbial communities in acid mine drainage. Applied and Environmental Microbiology 77(3): 991-999. 